\title{
The Effect of Work Satisfaction and Downward Communication on Performance of West Aceh POLRES With Intrinsic Motivation as a Mediation Variable
}

\author{
Mufti Muhammad $^{1}$, Said Musnadi ${ }^{2}$, Nurdasila Darsono ${ }^{3}$ \\ ${ }^{1}$ Master of Management Graduate Program, Syiah Kuala University, Banda Aceh, Indonesia \\ ${ }^{2}$ Economic Faculty, Syiah Kuala University, Banda Aceh, Indonesia \\ \{muftimuhammad@gmail.com\}
}

\begin{abstract}
This study aims to determine the effect of job satisfaction and downward communication both simultaneously and partially on intrinsic motivation and its simultaneous impact on Employee Performance on Personnel Performance in West Aceh Police. This research was conducted at the West Aceh District Police. As objects of this study are job satisfaction, downward communication, intrinsic motivation, and personal performance. The subject of this study was the West Aceh Police Resort Personnel. The population in this study was 441 personnel from West Aceh Police. Sampling using the stratified random sampling method. In this study the total indicators used were 25, then a sample of 120 samples was used. From the results of the study, it was found that Intrinsic Motivation which is considered to have the most influence on the performance level of the West Aceh Police Resort because this variable is the variable that has the largest Beta coefficient (0.37) compared to other variables such as Downward Communication and Job Satisfaction. In fact, job satisfaction was not proven to have a significant influence on improving personnel performance because the $\mathrm{H} 1$ hypothesis was rejected.
\end{abstract}

Keywords: Job Satisfaction, Downward Communication, Intrinsic Motivation, Personnel Performance, West Aceh Police

\section{Introduction}

One of the decisive aspects of achieving organizational performance is employee performance. If the employee's performance is not good, the results obtained are also not good so that the goals desired by the organization cannot be maximally achieved. For this reason, attention from office leaders to meet personnel needs is highly expected, so that employee performance will be good. Likewise for the Indonesian National Police (POLRI) institutions. Personnel who have good performance will always make changes in a better direction.

Many obstacles can be suspected as the cause of the low performance of the police personnel. One of them is Intrinsic Motivation. Intrinsic motivation itself is the motivation that is formed within ourselves when we do something without a reward from the environment. We simply enjoy a certain activity or view it as an opportunity to explore, learn, or actualize our own potential [1]. 
If the motivation from within has not been seen from the members of West Aceh Police, then the impact is on the performance of the person concerned and cumulatively influences the performance of the West Aceh Resort police.

Downward Communication. Downward communication is the delivery of information from superiors to subordinates in accordance with the structure in the organization. The use of this communication is very effective for delivering instructions, directing, controlling the subordinates. Communication can be written or oral which can be adjusted to the context and content. The message that is delivered to downward communication must be clear and easy to understand, especially if it is a command. Often the failure of communication is caused by differences in the point of view between communicators and communicants.

The purpose of this study is to test and analyze:

1. The Influence of Job Satisfaction on Intrinsic Motivation at the West Aceh Police Station

2. The Effect of Downward Communication on Intrinsic Motivation at the West Aceh Police Station

3. Effect of Job Satisfaction on Personnel Performance of West Aceh District Police

4. Effect of Downward Communication on the Performance of Personnel at West Aceh Police

5. Effect of Intrinsic Motivation on Personnel Performance of West Aceh Police

6. Effect of Job Satisfaction on Personnel Performance of West Aceh Police, through Intrinsic Motivation.

7. Effect of Downward Communication on the Performance of Personnel of West Aceh Police through Intrinsic Motivation.

\section{Literature Review}

\subsection{Employee Performance}

According to Kane [2], performance is not a person's characteristics, such as talent or ability, but is a manifestation of talent or ability itself. This opinion shows that performance is a manifestation of ability in the form of real work. Performance in relation to position is defined as the results achieved relating to the function of the position in a certain period of time [3]. According to Mondy \& Mondy [4] when used as a basis for decision making, employee performance evaluation can be very useful. But to be reliable, the performance appraisal must be fair and impartial, so that it can constructively capture key parameters of employee performance. Ideally, the measure of employee performance must be known by employees as the core that determines job expectations, where employees can not only measure actual performance but also be motivated to achieve established criteria. Employee performance influences the success of an organization if good the performance of employees of an organization will be good for the organization in the eyes of the community [5].

\subsection{Intrinsic Motivation}

Extrinsic motivation occurs when we are motivated to behave or engage in an activity to get a prize or avoid punishment. In this case, the employee is involved in behavior not because he enjoys it or because he feels satisfied, but to get something in return or avoid something unpleasant [6]. According to Suparta [7], intrinsic motivation involves involvement in behavior because it is personally beneficial; basically, doing an activity for its own sake rather than the 
desire to get external rewards. Basically, the behavior itself is the expected reward. Maznah, Ma'ruf, \& Sofyan [8] convey the dual motivation theory which suggests 16 (sixteen) factors that can motivate someone to work optimally known as intrinsic work motivation and extrinsic work motivation. Intrinsic work motivation is the motivation that is directly associated with the implementation of tasks, which include: recognition, achievement, possibility to grow, the possibility of progress and the work itself.

\subsection{Downward Communication}

Downward communication is the flow of information and messages from a higher level in the organization to a lower level. Effective downward communication is very important for organizational success [9]. In other words, the message flow starts at the top of the organizational hierarchy and moves down to the lower level. The response to a communication from below moves up on the same track. [10]. Ideal communication occurs when the message to be conveyed to someone is well received. The message will be carried out well and guaranteed to be effectively implemented when accompanied by other factors for the communication process [11].

\subsection{Research Paradigm}

For this research the paradigm used is as follows:

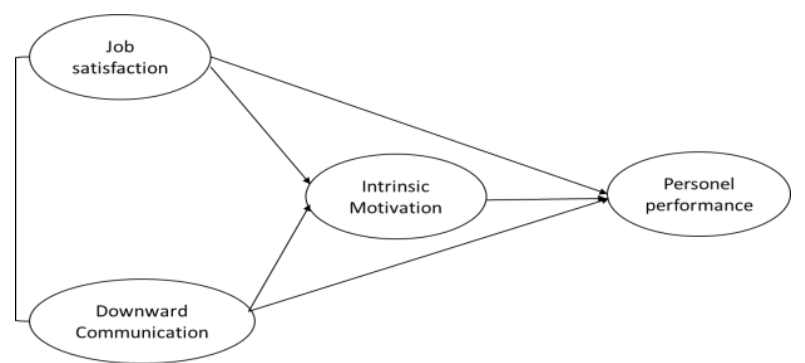

Figure 1. Research Paradigma

\subsection{Hypothesis}

Based on the framework described earlier, the hypothesis proposed in this study are:

H1.Job Satisfaction, Downward Communication, Intrinsic Motivation and Personnel Performance in West Aceh Police have been good

H2. Job Satisfaction influences Intrinsic Motivation in West Aceh Police

H3. Downward communication has an effect on Intrinsic Motivation at the West Aceh Police Station

H4.Job Satisfaction influences the Personnel Performance of West Aceh Police

H5.Downward Communication affects the Performance of Personnel of West Aceh Police

H5.Intrinsic Motivation affects the Performance of Personnel of West Aceh Police

H7.Job Satisfaction influences the Personnel Performance of West Aceh Police through Intrinsic Motivation.

H8. Downward communication affects the performance of the West Aceh Police Station Personnel through Intrinsic Motivation. 


\section{Research Methods}

\subsection{Location and object research}

This research was conducted at the West Aceh District Police. The object of this study relates to job satisfaction, downward communication, intrinsic motivation, and the performance of West Aceh District Police personnel.

\subsection{Sampling}

The population in this study were all personnel of the West Aceh Police, namely as many as 441 people. The sample is a portion of the number and characteristics of the population. In this study the total indicator used was 24 , then a sample of 120 samples was used.

\subsection{Data analysis method}

The data analysis technique used in this research is The Structural Equation Modeling (SEM) of statistical software package AMOS 22.0 for hypothesis testing. The SEM equation model is a set of statistical techniques that allows the testing of a series of "complex" relationships simultaneously. Testing this hypothesis is to analyze the value of Critical Ratio (CR) and Probability $(\mathrm{P})$ value of the data if compared to the required statistical limitation, that is above 1,96 for $\mathrm{CR}$ value and below 0,05 for P-value (probability). If the results of the data show the value that meets the requirements, then the proposed research hypothesis can be accepted.

\section{Result And Discussion}

\subsection{Test Measurement Model}

The following figure shows the relationship between indicators and unobserved variables (latent variables) in the Measurement Model.

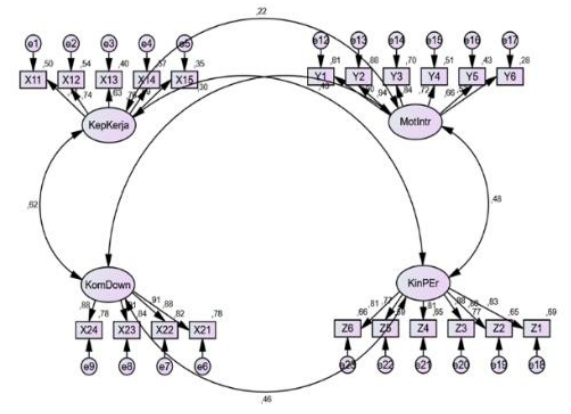

Figure 2. Measurement Model with loading Factor

The results of the measurement test showed that some indicators of the research variables have a value of factor loading below 0.5 . The following table shows net measurement results that can be included in structural testing. 
Table 1. Loading Factor Measurement Model

\begin{tabular}{lllll}
\hline No & Indicators & & Variable & Estimate \\
\hline 1 & X11 & $<---$ & Job satisfaction &, 706 \\
\hline 2 & X12 & $<---$ & Job satisfaction &, 738 \\
\hline 3 & X13 & $<---$ & Job satisfaction &, 632 \\
\hline 4 & X14 & $<---$ & Job satisfaction &, 755 \\
\hline 5 & X15 & $<---$ & Job satisfaction &, 588 \\
\hline 6 & X21 & $<---$ & Downward communication &, 982 \\
\hline 7 & X22 & $<---$ & Downward communication &, 915 \\
\hline 8 & X23 & $<---$ & Downward communication &, 884 \\
\hline 9 & X24 & $<---$ & Downward communication &, 899 \\
\hline 10 & Y1 & $<---$ & Intrinsic motivation &, 939 \\
\hline 11 & Y2 & $<---$ & Intrinsic motivation &, 839 \\
\hline 12 & Y3 & $<---$ & Intrinsic motivation &, 717 \\
\hline 13 & Y4 & $<---$ & Intrinsic motivation &, 658 \\
\hline 14 & Y5 & $<---$ & Intrinsic motivation &, 528 \\
\hline 15 & Y6 & $<---$ & Intrinsic motivation &, 830 \\
\hline 16 & Z1 & $<---$ & Personnel performance &, 804 \\
\hline 17 & Z2 & $<---$ & Personnel performance &, 877 \\
\hline 18 & Z3 & $<---$ & Personnel performance &, 808 \\
\hline 19 & Z4 & $<---$ & Personnel performance &, 766 \\
\hline 20 & Z5 & $<---$ & Personnel performance &, 810 \\
\hline 21 & Z6 & $<---$ & Personnel performance &
\end{tabular}

From table 1 above shows that all the indicators included in the model have been eligible to be included in the next data processing. The result of the model test is shown in table 2 below;

Table 2. Criteria Goodness of Fit Measurement Models

\begin{tabular}{|c|c|c|c|}
\hline Criteria index & Cut-off Value & Result of analysis & $\begin{array}{l}\text { Model } \\
\text { Evaluation }\end{array}$ \\
\hline Chi-Square & Expected to be small & 279,286 & Good \\
\hline CMIN/DF & CMIN/DF $<2$ & 2,381 & Not good \\
\hline GFI & $\geq 0,90$ & & Good \\
\hline & & 0,917 & \\
\hline AGFI & $\geq 0,90$ & 0,914 & Good \\
\hline CFI & $\geq 0,90$ & 0,947 & Good \\
\hline Baseline Comparisons & Approaching 1 & $\begin{array}{l}>0,5 \text { for NFI, IFI, TLI } \\
\text { and CFI }\end{array}$ & Good \\
\hline $\begin{array}{l}\text { Parsimony Adjusted } \\
\text { Measures }\end{array}$ & $0-1$ & $\begin{array}{l}\text { Pration, PNFI, PDCFI } \\
\text { beetwin } 0-1\end{array}$ & Good \\
\hline RMSEA & $<0,08$ & 0,108 & Not good \\
\hline AIC & Default Model < Saturated & $\begin{array}{l}504< \\
573 \\
<2127\end{array}$ & Good \\
\hline ECVI & $\begin{array}{l}\text { Default Model in betwen } \\
\text { Saturated \& Independence }\end{array}$ & $\begin{array}{l}4,235< \\
4,821< \\
17,880\end{array}$ & Good \\
\hline
\end{tabular}




\subsection{Structural Equation Modelling Analysis}

Analysis of data processing result at full stage of SEM model is done by doing conformity test and statistical test. Results of data processing for the analysis of full SEM model shown in Figure 3.

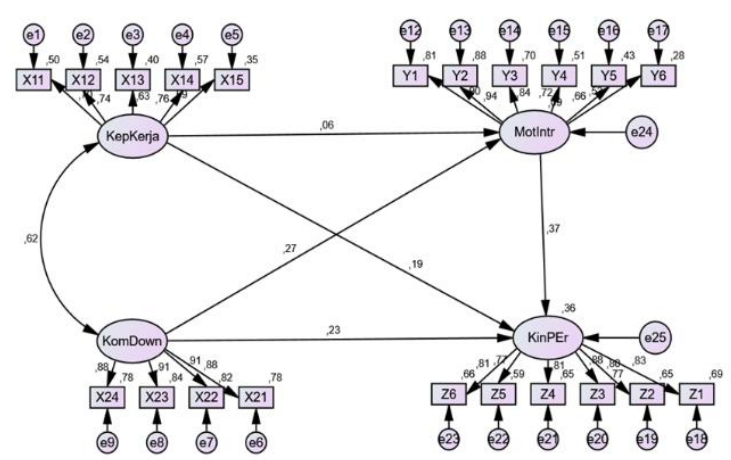

Figure 3. Structural Equation Model

\subsection{Hypothesis Testing}

After all, assumptions can be met, then will be tested hypothesis .. Testing 7 hypothesis of this research is done based on Critical Ratio (CR) value of a causality relationship. as in table 3 below.

Table 3. Result of hypothesis

\begin{tabular}{llccc}
\hline No & \multicolumn{1}{c}{ Hypothesis } & $\begin{array}{l}\text { CR Cut } \\
>\mathbf{1 . 9 6}\end{array}$ & $\begin{array}{c}\text { off } \\
\text { Put off }<\mathbf{0 , 0 5}\end{array}$ & Remark \\
\hline $\mathbf{1}$ & Job satisfaction to Intrinsic motivation & 0,409 & 0,683 & $\mathrm{H}_{1}$ Rejected \\
\hline $\mathbf{2}$ & Job satisfaction to personil performance & 4,179 & $* * *$ & $\mathrm{H}_{2}$ Accepted \\
\hline $\mathbf{3}$ & $\begin{array}{l}\text { Downward communication to Intrinsic } \\
\text { Motivation }\end{array}$ & 2,053 & 0,040 & $\mathrm{H}_{3}$ Accepted \\
\hline $\mathbf{4}$ & $\begin{array}{l}\text { Downward communication to personil } \\
\text { performance }\end{array}$ & 4,180 & $* * *$ & $\mathrm{H}_{4}$ Accepted \\
\hline $\mathbf{5}$ & $\begin{array}{l}\text { Intrinsic motivation to personel } \\
\text { performance }\end{array}$ & 4,126 & $* * *$ & $\mathrm{H}_{5}$ Accepted \\
\hline
\end{tabular}

From the results of structural testing, there is a hypothesis that is accepted and the tone rejected. Hypothesis 1 which examined the effect of job satisfaction on intrinsic motivation was rejected because it did not fulfill the conditions accepted. Whereas the other 4 direct hypotheses, namely $\mathrm{H} 2-\mathrm{H} 5$ are accepted. This means that there is a significant influence between the independent and dependent variables on each of these hypotheses.

In other words, the variable has the effect of increasing the dependent variable as long as the independent and intervening variables can be increased by the leadership in this case the West Aceh Police Chief 


\subsection{Direct and Indirect Influence}

To see the direct and indirect influence of the variables found in this study, it must first be seen the number of coefficients obtained. Based on the results of processing using AMOS 22 software. Based on the result of the coefficient of structural equation modeling the direct and indirect effect are presented in Table 4;

Table 4. The direct and indirect effect

\begin{tabular}{lllc}
\hline No & Indirect Effect & Result of the Sobel test & Remark \\
\hline $\mathbf{1}$ & $\begin{array}{l}\text { Job Satisfaction in Personnel } \\
\text { Performance through Motivation }\end{array}$ & $\begin{array}{l}\text { Because the result not } \\
\text { significant so there is no } \\
\text { indirect influence }\end{array}$ & $\begin{array}{l}\text { There is no indirect } \\
\text { influence }\end{array}$ \\
\hline $\mathbf{2}$ & $\begin{array}{l}\text { Downward communication on } \\
\text { personnel performance through } \\
\text { motivation }\end{array}$ & $2,042>1,96$ & $\begin{array}{l}\text { there is no indirect } \\
\text { influence in partial }\end{array}$ \\
\hline
\end{tabular}

Because the direct influence of Downward Communication on Personnel Performance is significant and the indirect effect through the Intrinsic Motivation variable is also significant, the variable of Intrinsic Motivation, in this case, is called Partial Mediation.

\section{Conclusion And Recommendation}

\subsection{Conclusion}

1. Testing of hypothesis $1(\mathrm{H} 1)$, the namely descriptive hypothesis is done by using one sample test with a 3.4 cut-off value with the results as stated in the One-Sample Test table. It can be seen that all indicators on the 4 variables have significantly below 0.05 . Thus it can be concluded that all the variables in this study are Job Satisfaction, Downward Communication, Intrinsic Motivation, and Personnel Performance are good

2. From the Confirmatory test, there are 3 indicators that do not meet the requirements because they have a number of loading factors below the required one, namely 0.5 . So that the three indicators namely X25, X26, and Z7 must be delimited from the model.

3. In the first Goodness of Fit test, it was concluded that the existing measurement model is not fully fit with the existing data so that the model must be improved using Modification Indices, especially to improve the performance of CMIN / DF and RMSEA which are still outside the required limits. After repairing the model, CMIN / DF and RMSEA have entered the required boundary range so that the measurement model is considered to have fulfilled the requirements to proceed to the structural stage.

4. From the results of testing the hypothesis, of the 5 direct hypotheses tested only 1 is not significant, namely the influence of Job Satisfaction on Intrinsic Motivation because it has a $\mathrm{CR}$ and $\mathrm{P}$ value that does not meet the requirements.

5. Testing indirect to see the effect of job satisfaction on Personnel Performance proved not to meet the requirements for further testing because the influence of IV on MV is not significant. However, for testing the second indirect, the two specified conditions have been fulfilled so that it can proceed to indirect testing using Sobel Test, Aroian Test, and Goodman Test. The three results of the test produce a test statistic above 1.96, so it can be said that $\mathrm{H} 1$ is accepted. In other words, it can be interpreted that the 
Intrinsic Motivation variable can act as a mediator that relates Downward Communication to the Performance of West Aceh Police Precincts.

6. Because of the direct influence of Downward Communication on personnel performance is significant and the effect is not direct which through the Intrinsic Motivation variable is also significant, then the variable of Intrinsic Motivation, in this case, is called Partial Mediation.

\subsection{Recommendation}

1. From the findings of this study, it is proven that Intrinsic Motivation is considered to have the most influence on the level of performance of West Aceh National Police personnel because this variable is a variable that has a large Beta coefficient (0.37) compared to other variables such as Downward Communication and Job Satisfaction. In fact, job satisfaction was not proven to have a significant influence on improving personnel performance because the $\mathrm{H} 1$ hypothesis was rejected.

2. Therefore, if personnel performance becomes the main concern for improvement, it must be done through increasing Intrinsic Motivation by improving the quality of Downward Communication carried out between superiors and prisoners in the ranks of the West Aceh Police. To increase the work motivation of West Aceh police officers, the indicators that need to be improved are those that have the lowest average value, namely "Interest in deepening work to avoid problems in carrying out work" with a value of 3,875. After that, the second lowest value indicator that needs to be improved is "Feeling the importance of working as part of employee contributions to the company" with an average value of 3,992.

\section{REFERENCES}

[1] D. Coon and J. O. Mitterer, Psychology: A journey, 5th ed. Belmont, CA: Cengage Learning, Inc, 2014.

[2] J. S. Kane, "The conceptualization and representation of total performance effectiveness," Hum. Resour. Manag. Rev., vol. 6, no. 2, pp. 123-145, Jun. 1996.

[3] A. D. Indrawati, "Pengaruh kepuasan kerja terhadap kinerja karyawan dan kepuasan pelanggan pada rumah sakit swasta di kota Denpasar," J. Manag. Strateg. Bisnis dan Kewirausahaan, vol. 7, no. 2, pp. 135-142, 2013.

[4] R. W. Mondy and J. B. Mondy, Human resource management, 13th ed. Essex, England: Pearson Education Limited, 2012.

[5] Husaini, S. Musnadi, and Amri, "Pengaruh kepribadian, komitmen kerja dan kematangan emosional terhadap motivasi kerja dan dampaknya terhadap kinerja perawat di Badan Layanan Umum Daerah (BLUD ) Rumah Sakit Jiwa Aceh,"J. Magister Manaj. Fak. Ekon. dan Bisnis Unsyiah, vol. 1, no. 1, pp. 25-34, 2017.

[6] A. Pujadi, "Faktor-faktor yang mempengaruhi motivasi belajar mahasiswa: Studi kasus pada Fakultas Ekonomi Universitas Bunda Mulia,” Bus. Manag. J. Bunda Mulia, vol. 4, no. 2, pp. 40-51, 2007.

[7] A. G. Y. Suparta, "Pengaruh motivasi intrinsik, komunikasi, dan kompensasi finansial terhadap kinerja karyawan pada PT Maharani Prema Sakti Denpasar,” E-Jurnal Manaj., vol. 2, no. 5, pp. 530-540, 2013.

[8] J. Maznah, Ma'ruf, and I. Sofyan, "Pengaruh lingkungan organisasi, kepuasan kerja terhadap motivasi kerja serta implikasinya pada kinerja pegawai Politeknik Negeri 
Lhoseumawe," J. Ilmu Manaj. Pascasarj. Univ. Syiah Kuala, vol. 1, no. 1, pp. 1-20, 2012.

[9] L. D. Pool and P. Sewell, "The key to employability: Developing a practical model of graduate employability,” Educ. Train., vol. 49, no. 4, pp. 277-289, 2007.

[10] A. Yuningsih and D. Mulyana, "Communication Pattern And Skill Of Leaders In Private University Management," MIMBAR, J. Sos. dan Pembang., vol. 33, no. 1, p. 166, Jun. 2017.

[11] E. Kurniawan, M. Yunus, and S. Musnadi, "Pengaruh disiplin, motivasi, komunikasi dan kepemimpinan terhadap prestasi kerja karyawan pada PT Pupuk Iskandar Muda Aceh Utara,” J. Ilmu Manaj. Pasca Sarj. Univ. Syiah Kuala, vol. 1, no. 2, pp. 163-182, 2012. 